Article

\title{
Long Live the Heritage of Petroleum-Discoveries of Former Oil Sites in the Port City of Dunkirk
}

\author{
Stephan J. Hauser ${ }^{D}$ \\ Faculty of Architecture and the Built Environment, Delft University of Technology (TU Delft), \\ 2628 BL Delft, The Netherlands; s.j.hauser@tudelft.nl
}

Received: 11 March 2020; Accepted: 29 April 2020; Published: 1 May 2020

check for updates

\begin{abstract}
In the early days of the petroleum industry, oil infrastructure had a short lifespan. Individuals were creating their own company and competing with others, without the financial means of current great companies. Many oil facilities were established in port cities like Dunkirk, because they were the entrance gates to many nations. In the case of Dunkirk, many former oil sites became houses and schools in the current urban tissue, and official records lost track of many others. The limited data available on official records to inform the people on the pollution of their soil is a threat to their safety and health, and an obstacle for the planning strategies of public authorities. The analysis of archival documents, past and present aerial pictures, paintings and mapping techniques related to geographic information systems (GIS) can reveal lost industrial sites, and thus indicate potential pollution. This paper investigates the oil history of Dunkirk as a background for its petroleum history and its transferability to other petroleum related cities. A cross analysis of sources will attempt to complete French files and locate oil sites. The objective is to illustrate the transformation of former oil sites, and why the current land use is often not compatible with its history.
\end{abstract}

Keywords: energy transition; environmental history; geographic information systems; health; oil industry; urban history; urban planning

\section{Introduction}

Since the mid-19th century, the growth of many port cities has developed in tandem with the petroleum industry in those territories [1]. The architecture and infrastructure of the oil industry - such as refineries, storage sites, transformation industries and distribution networks-shaped entire areas in strategic ports for national governments and global trade. Harbors were pathways between oil products of the world and the hinterland. The first establishments of oil industries in Western European port cities occurred in the middle of the ninetieth century, as companies imported oil from the United States or Russia and built storage sites and refineries in port areas. The growth of the oil industry went hand in hand with a rapid expansion and consumption of space. The oil industry gradually increased its influence on the global petroleumscape over the next 160 years-through its financial power, infrastructure network, and the access of its leaders to political positions [2] in turn affected the physical spaces of cities and landscapes and their depiction, and also the regulating systems of cities, provinces and nations [3]. After the Second World War, petroleum companies confirmed their dominance over economic activities. Their products became prevalent in all aspects of daily life.

The oil industry is still going strong, but it has moved outside the city center and has often left remnants behind even after the closing of its facilities and the destruction of its infrastructure. Going beyond its tangible meaning, oil heritage is here not only understood as buildings, visible infrastructure and network, but also as its environmental and regulatory legacy. The influence of the petroleum industry on the creation and application of rules potentially affecting its activity is tremendous [4]. The pollution of soil and water can be considered as the unseen heritage of oil activities, which now affects port cities and 
has direct consequences for works and incidents relating to the storage and transformation of oil [5]. Many cities will have to deal with this underground pollution. Port cities are particularly important, because of the extensive land dedicated to this industry on their territory. Port cities struggle to transform this dying and cumbersome industrial heritage to improve their competitiveness and attractiveness. Authorities of port cities also have to consider climate change and the potential swamping of these areas, which would spread the pollution even further. In the case of Dunkirk, many petroleum industries settled in flood zones. If the heyday of oil could end in a near future, its legacy will remain and haunt the energy transition and the planning of many port cities-with pollution, planning limitations, and influence on regulations.

The port city of Dunkirk, on the north coast of France near the Belgian border, is an excellent example of how old petroleum activities can become obstacles to the renewal of a city. The cities included in this research were Dunkirk, Coudekerque-Branche, and Saint-Pol-sur-Mer, all part of the metropolitan area of Dunkirk. These are the main areas where the oil industry thrived. The French nation-state always considered the port city as a strategically important place, first for military purposes, then for infrastructure and trade. Its relevance for the topic comes from its relationship with petroleum. The oil industry reshaped the port city at the beginning of the 20th century by creating neighborhoods for its employees. The "Cité des Ingénieurs" is the most well-known. It hosted the family of company executives in a luxury complex of 23 houses, right next to the refinery. Concerns over its proximity with a dangerous site and with the development of industries in the port area, led the employees to slowly abandon the "Cité". Authorities-of the port and the city-are trying to transform this industrial past, through cleaning and an industrial regeneration, to renew the image and the economic life of the metropolitan area. However, the legacy of oil activities since the $1860 \mathrm{~s}$ is a great hindrance to this renewal.

The Second World War, which destroyed three quarters of Dunkirk, had an influence on the petroleum pollution in the city. Considering how strategic this resource was during the war, both forces destroyed storages and refineries along with the rest of the city (Figure 1). The petroleum that these facilities contained ended up polluting the soil of the port city. The post-war reconstruction of petroleum facilities on the same sites prevented any cleaning process; there was a need for inhabitants and public authorities to fasten the renewal of the port and an absence of environmental considerations before the 1970s.

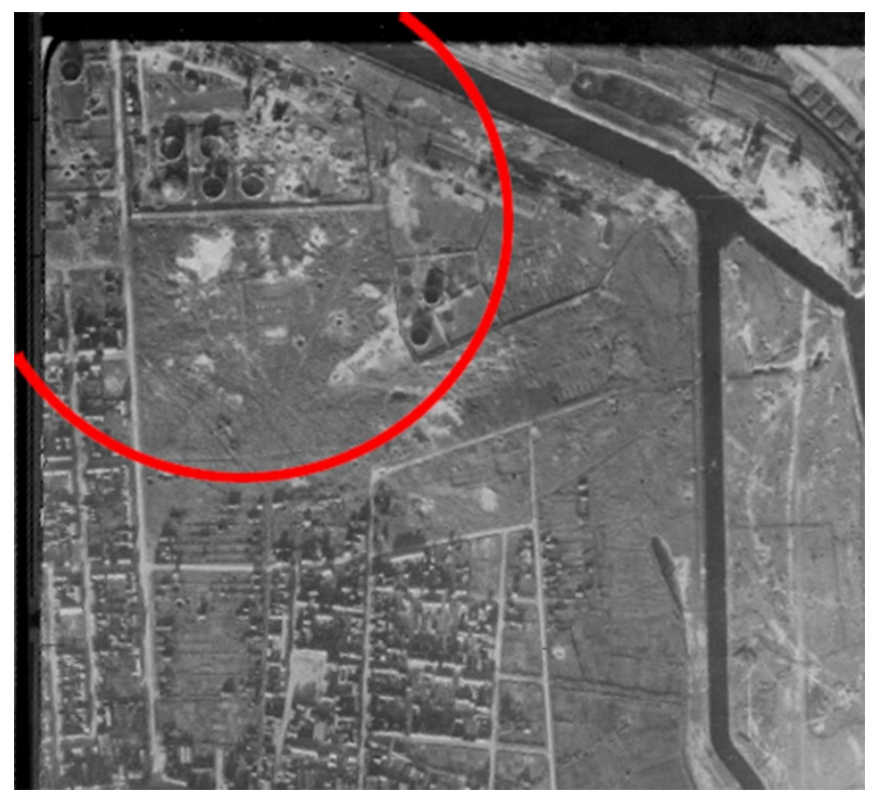

Figure 1. Aerial picture of Dunkirk in 1944 with the destroyed oil storages. The concentration of impact around the site reveals its strategic nature. Picture from the French National Institute of Geographic and forest information, or IGN (Institut national de l'information géographique et forestière). (C) IGN 
As for the future, pollution from oil activities must be viewed as a form of petroleum heritage, leaving a legacy that we need to consider. Beyond the pollution caused by this resource, citizens, private and public stakeholders must also challenge the pollution of its products, infrastructure and influence. Now, in the current urban tissue, these unknown pollutions are like mines in the soil; "Pollution mines" threatening the health of inhabitants and obstacles in the transformation of the port city. Who can be responsible for the pollution from 150 years ago? One of the problems with this industry is that, for many of these former oil sites, nothing remains in the current city scape. Although visible infrastructure disappeared at ground level, replaced with new buildings and functions, the underground situation persisted. What happened to this heavily contaminated soil remains unknown. With no details regarding the precise location of such sites, and considering how facilities vanished, oil activities transformed the underground city into a landmine, with heavily polluted areas often standing at the center. Private and public actors of the port city of Dunkirk are trying to transform this burden into opportunities. While one of the two post-war refineries is being dismantled and cleaned, the other has transformed into a center for the education of international employees of the company. The company total also exploit an infrastructure dedicated to research on new bio-fuels next to this area. The activity remains oil-related, and oil still has a huge impact on the port city. The future will say if the new building rising after the cleaning of the first refinery will start turning the page of oil in Dunkirk.

The questions here are what consequences oil activities can have on the urban planning of port cities in the environmental discourse and how authorities have managed this industrial past. How can the information lacking in official records be rediscovered? This paper answers this first by uncovering the life and death of the oil industry in Dunkirk since the 1860s, its forgotten past and its legacy through archival sources i.e., historic maps, images, newspaper. It then reveals the influence of oil companies on the planning of the port city, by geo-referencing historical maps with the use of geographic information systems (GIS) software. A diversity of other sources comes to support this geo-referencing and ensure the location of former petroleum sites, not indicated on old maps. The role of GIS is determinant to illustrate both threats and possibilities for public authorities. The findings of the paper aim to highlight environmental issues of the remains of oil and their implications on the urban form.

The aim of this study is to highlight the importance of historical research in the planning and development of former "oil cities". The article reveals that the lack of knowledge on the location of petroleum sites is leading to incompatibilities between the former and the actual land use of Dunkirk. The oil past of the French port city made it relevant for this analysis, but is part of a wider research on the influence of oil companies in Northwest Europe.

\section{Theory and Methods}

The specificities of port cities in urban planning and regional socio-economic impacts also need to be pointed out. In a book published in 2016, Mega emphasizes the role of coastal cities, the risks they have to face, the opportunities that they represent and their link to local and global citizens [6]. Taking Hamburg as one example, she shows how the development of a port is beneficial to many different actors; not only locally, but also on a greater scale. She demonstrates in these papers the role of comprehensive and integrated policies to regenerate coastal cities. Climate change, natural hazards and maritime activities are threats to the sustainable development of coastal areas. To challenge these obstacles, Mega stresses the need for anticipative and inclusive strategies, with strong institutions and an efficient enforcement of rules. Similarly to Mega, Fenton, in 2020, highlights the central role of such coastal areas in sustainable development and transport systems [7]. Taking Stockholm as an example, he demonstrates the pressures and challenges that port authorities have to deal with and the transferability of these issues to other places. Among others, he mentions, as challenges for the urban redevelopment, the maintenance of port infrastructure, the management of environmental risks and the objective of becoming fossil-free ports.

One of the great points developed by Fenton is the important influence of petroleum companies on the redevelopment policies of port cities. Urban planning historian Hein picks up a similar theme 
highlighting the role of petroleum and its products in the energy landscape and how it shaped the built environment of port cities [8,9]. With Rotterdam as an example, she demonstrates the similarities of challenges in port development around the world. Oil actors worldwide shaped things in different ways, but Hein confirms that "together they function as a global palimpsestic petroleumscape". She defines this notion as the interconnections of physical structures and imaginaries of the oil industry and how it impacted the built environment of cities. The dominance of the oil industry over the planning and land allocation in Rotterdam led to multiple relocations of its infrastructure since the 1860s, until claiming land over the North Sea after the Second World War. In the case of Rotterdam, the energy transition will be a major challenge for the authorities of the port city, as its history is similar to Dunkirk on a much greater scale. However, dealing with the current and well-known infrastructure does not mean forgetting about the consequences of lost and past petroleum sites.

Prior studies developed the importance of historical maps or aerial pictures in combination with geographic information systems. In a French article, Delahaye et al. in 1999 were already using declarations of industrial establishment from archives with maps of the cadastre and GIS as a tool for urban managers to identify chemical risks on the left bank of the Seine [10]. Similarly, Gilliland and Novak (2006) used GIS together with fire insurance plans to position past industries on current maps [11]. Inspired by this technique, Leonard and Spellane used archival research and chemistry to unveil the petroleum past of Newton Creek in New York City [12]. The French heritage curator Moufflet supported the development of these techniques of digital mapping, as they "should encourage archivists to multiply initiatives" and develop its possibilities [13]. In 2019, Brétt et al. adopted this mechanism, combining historical documents with a web-mapping application to uncover the industrial past of the Czech-German borderland [14]. At the same time, they named these vanished facilities "technical culture heritage", highlighting their cultural role and the social link of this industrial heritage, while emphasizing the importance of their transformation.

Many authors developed different perspectives on the re-use or reclamation of post-industrial lands. Kirkwood, in 2003, illustrated the challenge of transforming former industrial sites around New York [15]. Using the term "brownfields" to describe these areas, he used a definition from the United States Environmental Protection agency of 1996: "Abandoned or underused industrial and commercial sites where redevelopment is complicated by real or perceived contamination". In his explanation, developers perceive these lands as having immediate potential for economic development, considering the pressure for redevelopment and their location. As an engineer working in the conservation of industrial heritage, Tempel also reflects on the pollution, transformation and perception of the industrial heritage. He discusses mainly the reclamation of the built heritage, still visible [16]. His vision of the cleaning process often goes with a destruction of the industrial history. However, Tempel later highlights the recent yet growing collaboration between companies and nature conservation groups in the remediation of former industrial sites. His article deals however with modern time industries, still visible when the reclamation happens and where authorities are aware of the pollution. The implications of long lasting and well-known industries on the urban tissue are extensively discussed. Nevertheless, methods for identifying the sites and understanding the consequences of ancient and lost industrial activities on the urban planning of modern cities are less developed. Locating the legacy of the oil industry is partly problematic due to the lack of available information on its development. Visits to the county archives of Lille and the one in the Learning Center of Dunkirk contributed the primary materials for this research. Drawings, paintings, letters and authorizations brought new elements and precious illustrations on the influence of oil industries and owners on the development of the port city. These documents also revealed the evolution of security, health and planning measures related to oil activities.

Tracing precise details, i.e., location, dates, pollution, cleaning of oil sites is a challenge considering the period and the absence of strict documentation. This study uses online archival sources of the website "Géorisques" [17]. The French Ministry of the Ecological and Inclusive Transition, together with the Geological and Mining Research Bureau (Bureau de Recherches Géologiques et Minières or BRGM), manage this website. This official website records the creation of industrial sites but is, for instance, 
unable to indicate how long some petroleum activities remained active. More disturbing is the absence of precision on the location of many of them. Authorizations of past authorities, here the regional representative of the government, on the establishment of such industries record the establishment of these industrial sites, however not systematically and precisely. Occasionally, the website can mention the name of an old road which can be traced back to an existing one with a new name. Often, the files register the name of the industrial owner as the name of the site, with or without geographic information. This results from the registration process implemented by the imperial decree. In his article on the development of industries in the metropolitan area of Dunkirk from 1957, Thelliez is refereeing to some of these names, explaining their history and origin [18]. It gives additional pieces of information on their location or historical developments. To confirm the actual location of these oil-related sites, another source intervenes.

The paper uses the "Géorisques" repository as a basis. Its incomplete files with, among others, missing locations of polluted sites, are the one used to start the research. The category used in this website is "Petroleum refining, distillation and rectification and/or storage of minerals and oils". The literature and archival documents provide additional information in order to find their position. The study then uses the "IGN" (Institut national de l'information géographique et forestière) online service to confirm [19], when possible, the indications found in articles and archives through the analysis of its aerial pictures.

IGN grants, through its websites, free access to geographic data for the public. Its extension "Remonter le temps", literally "go back in time", provides aerial pictures of Dunkirk since 1920. Hence, there is a limitation to the combination between literature and archival documents with these aerial pictures. If oil sites established before 1920 did not survive until then, it is impossible to confirm their location with these historical pictures. Clichés are not always in good quality or precise enough to ensure that the shape of the building on the picture is the factory being searched. They also do not cover the entire area. Yet, the gathered information of different sites sometimes makes up a body of evidence which can reveal lost oil sites.

Furthermore, the paper combines old maps and aerial pictures with the geo-referenced mapping of oil sites and the analysis of literature, planning regulations and land uses. Table 1 is summing up the different materials used in this article. This method uncovers lost and polluted sites while completing public records on oil-related industries. The cross analysis and results allow a better understanding of past and present land use strategies in former industrial cities and port cities like Dunkirk.

Out of the fifteen oil sites referenced in the area since the beginning of the oil industry, only eight have geographical information on "Géorisques". Files like the one on the "Raffinerie de pétrole du Nord", an oil refinery in Saint-Pol-sur-Mer, can give the name of a street-here "rue Péri" and an additional "at one hundred meters of the street Samaritaine" —and its date of creation-1924. Sometimes, however, it only indicates the name of a street or of the city/neighborhood; not enough to pinpoint its clear location. However, the combination of the website "Géorisques" with other archival sources can potentially fill this gap. 
Table 1. List of all the types of source material used in this research and their description.

\begin{tabular}{|c|c|c|c|}
\hline Name of the Source & Type & Description & Characteristics \\
\hline “Géorisques" & Online database & $\begin{array}{l}\text { Listing of all industrial sites } \\
\text { identified in France. }\end{array}$ & $\begin{array}{l}\text { Extensive listing and } \\
\text { classification but incomplete } \\
\text { files. Location and closing year } \\
\text { are often missing. }\end{array}$ \\
\hline "IGN" & Online database & $\begin{array}{l}\text { Online service giving access } \\
\text { to past and present aerial } \\
\text { pictures in France. }\end{array}$ & $\begin{array}{c}\text { Excellent quality of images, } \\
\text { but historical ones start only in } \\
1920 \text { in Dunkirk, and are limited } \\
\text { to specific areas and years. }\end{array}$ \\
\hline $\begin{array}{l}\text { Archives of the region } \\
\text { and the Learning } \\
\text { Center of Dunkirk }\end{array}$ & $\begin{array}{l}\text { Archival documents } \\
\text { and pictures/plans }\end{array}$ & $\begin{array}{l}\text { Archives of the North county } \\
\text { of France and of the } \\
\text { Learning Center of Dunkirk. } \\
\text { Give access to literature, } \\
\text { pictures, plans, letters and } \\
\text { minutes from the local } \\
\text { chamber of commerce. }\end{array}$ & $\begin{array}{l}\text { A great diversity of documents } \\
\text { available but not accessible } \\
\text { online. In many cases, } \\
\text { the description of the file in the } \\
\text { database does not detail the } \\
\text { content of the folder. }\end{array}$ \\
\hline $\begin{array}{l}\text { Literature on the } \\
\text { development of } \\
\text { industries }\end{array}$ & $\begin{array}{l}\text { Online and offline } \\
\text { literature }\end{array}$ & $\begin{array}{l}\text { Literature related to the } \\
\text { location of former industrial } \\
\text { sites in Dunkirk or in the } \\
\text { region, with their stories, } \\
\text { pollutions and influence on } \\
\text { the planning of cities. }\end{array}$ & $\begin{array}{l}\text { Online articles and books give } \\
\text { precious information on the } \\
\text { industry of the North of France. } \\
\text { However, some details on } \\
\text { Dunkirk's industrial past come } \\
\text { from one small book in the } \\
\text { archives of the city. }\end{array}$ \\
\hline $\begin{array}{c}\text { GIS (geographic } \\
\text { information systems) }\end{array}$ & Mapping software & $\begin{array}{l}\text { ArcGIS is the software used } \\
\text { to locate old industrial } \\
\text { facilities on the actual map } \\
\text { of Dunkirk. }\end{array}$ & $\begin{array}{l}\text { The overlapping of historical } \\
\text { maps on the actual and precise } \\
\text { plan of the city illustrates the } \\
\text { influence of the industry } \\
\text { in Dunkirk. }\end{array}$ \\
\hline
\end{tabular}

\section{Discoveries of Former Oil Sites}

On the 15 oil sites referenced on the official website "Géorisques", one can learn that private and public authorities cleaned or are cleaning only three, with two in the current urban tissue. Two decontaminated sites hosted dwellings, while the other one is being treated. The latter is on the territory of the port authority. As such, authorities of the port will transform the area to allow the settlement of a new activity. Except for these three former petroleum territories, all the others, at least 12, did not undergo any cleaning process. The private or public authorities transformed the use of the land without much consideration for the condition of the soil. At places of former oil sites, now part of the urban tissue, public authorities allowed the construction of housings, schools and parks. The existence of non-registered sites or lost authorizations between the 1860 s and the creation of the repository is also possible. This possibility illustrates again the image of "urban landmine".

After the first closings of petroleum sites, for which most of the closing dates are unknown, public and private authorities developed a diversity of land uses on former oil sites, with some receiving multiple purposes. Three former sites are now in industrial areas and one is still a storage site, which can partly explain the lack of remediation. An oil factory, a factory for the extraction of fatty substances from oil, a petroleum oil purification plant and a naphtha oil purification workshop did not have geographic indications. The transformation of these sites was impossible to verify, as the website lost track of them.

After two world wars, petroleum became a strategic resource that nations had to secure. However, since the 1860s, people invested in oil refineries or storages, creating at least fifteen sites in Dunkirk. During this period, the outskirts and the borders of Dunkirk, or the old port area, were the privileged places to meet the need of this growing industry. Figure 2 shows that with the development of the city and the urban sprawl, many oil sites ended up in densely populated areas at the end of the 19th century, and even more with the modern expansion of the metropolitan area. The first oil infrastructure in Dunkirk settled in the early stage of petroleum's industrial development. In 1861, J.B. Trystram, 
a businessman and later politician, created with his business partner Crujeot, the first refinery in the south-west of the old city [20]. Already working in the timber industry, Trystram invested in a refinery, outside of the main living area and the port but next to its sawmill, and imported oil from Pennsylvania. It was the first step of the city towards its oil-oriented future.

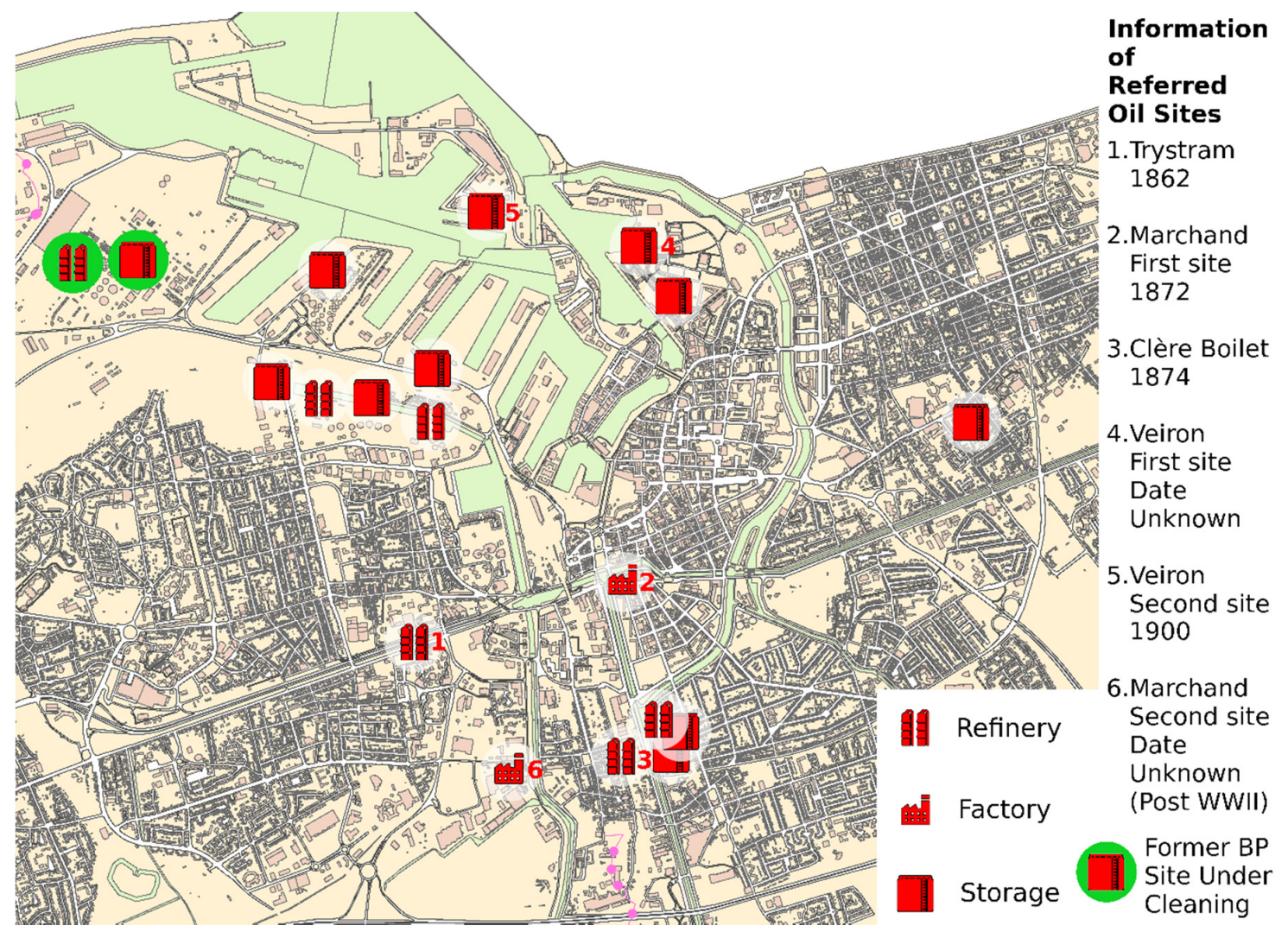

Figure 2. Mapping of the oil-related sites (refineries, factories and storages) that emerged since 1860 in the port city of Dunkirk. Made by the author and based on the actual map of the city from the Learning Center of Dunkirk.

\subsection{Misleading Cases: Savignon and Others}

The research revealed some former oil sites in Dunkirk, thanks to the availability of sources. The documentation, however, lost track of some others. The repository from "Géorisques" cannot locate nor give any information on all the oil sites that it references. The database is unable to mention or record them, because of their creation dates, size or lifetime. This situation concerns two sites: a naphtha oil purification workshop built in 1881, and an oil factory from 1893 . Official records lost track of these facilities, thus of all potential pollution of the soil in the city. This loss means that there are, in the port cities, patches of contaminated areas unknown to any authority.

A third infrastructure is more challenging to find. The official listing also references the petroleum oil purification plant of Savignon built in 1868 in the neighborhood of Petite-Synthe, but with no information. Thelliez in his article mentioned an oil-mill or work in this district [18], adding: "we know nothing about the Petite-Synthe oil mill destroyed during the last war, and not rebuilt on the spot". His article could not find information on the site either. Yet, the last part of the sentence suggests a later reconstruction, maybe elsewhere. The statement also indicates that the factory existed until the Second World War, thus, research through the aerial pictures of the IGN was possible.

The study found only one potential site in a picture of 1936 near the main road of this neighborhood. The area was reaching the limit of the urbanization of the port city. Yet, observations of the picture showed three small shapes that looked like silos in the middle of a residential area. With a much better 
quality, the next picture of the area was available in 1949. The same shape appeared in the same area, but the image allowed further investigation. Former analysis could have been taken for these silos, which were square-shaped extensions of the main building. Besides, the description given by Thelliez did not match with the facility being at the same position again. Hence, the documents could not provide enough information to locate the site and its research proved the quality of old aerial pictures to be potentially misleading.

\subsection{The Moving Industry of Marchand in 1872}

The article from Thelliez also mentions new elements on the site Marchand [18]. While the file on this factory does not provide any information on it except its opening date, 1872, Thelliez shares an interesting piece of information. The paragraph starts by mentioning that the following information is taking place after 1939: the site "formerly located at the corner of the canal of Bergues and the junction canal, without branching rail, has been rebuilt with ultra-modern equipment at Petite-Synthe, on the edge of the Bourbourg Canal, this time with excellent rail and river connections". Therefore, there were two sites linked to the oil site Marchand. The time frame allowed research on the IGN website to find both sites, the first before and the second after 1939.

The historic aerial pictures for Marchand's first site in the known area cannot give a precise location. The entire area along the canal was an industrial site, recognizable thanks to the long and successive roofs, typical of the northern French industry. In the current urban tissue, this zone became a residential area. For the second site however, only images from 1947 show a site on the described area. They illustrate the facility with connections to rail and water, as described in Thelliez' article and silos were visible (Figure 3). Although the place is still in an industrial area in the city of Dunkirk, recent images demonstrate settlements within this zone (Figure 4). Yet, private or public authorities did not carry out cleaning operation on this site, which implies that the potential pollution remains and that people are living on top of it.

Thelliez, before mentioning the location of the site Marchand, once again gives useful information on it in its article. Talking about the "oil mill Marchand", the article mentions: "the oil produced, cheap, was also of a more ordinary quality. The clientele, outside the local market, was mainly composed either of companies receiving various oils in bulk and reselling them in bottles under their brand, or of communities concerned with savings". "Géorisques" included the factory in the category "Petroleum refining, distillation and rectification and/or storage of mineral oils". By doing so, the website puts oil refineries and vegetable oil factories under the same category. Hence, the location of the site Marchand is still a discovery through this methodology; however, it is not one related to petroleum and great pollutions.

\subsection{Industry and Political Influence: The Case Clère-Boilet in 1874}

A book from J. Denise found in the archives of the Learning Center of Dunkirk enabled connections with incidents and political issues [20]. The author mentions that areat explosion and fire occurred in the refinery Clère Boilet (founded in 1874 Couderkerque-Branche) in May 1891, killing seven people. An analysis of the file from the website "Géorisques" on this same refinery revealed an extension of the conditions to run the facility in August 1891. These new rules were clearly the reaction of public authorities to the incident. The author of the book pointed out the surprise of a local newspaper to see that, after three fires in the refinery, public authorities still allowed it to function. The papers declared later on that it was thanks to the political support provided to M. Clère by M. Trystram, who, after opening its own refinery in 1861, became general counsel of the North province. This is an early illustration of the influence that oil companies and owners have on public authorities and political spheres. 


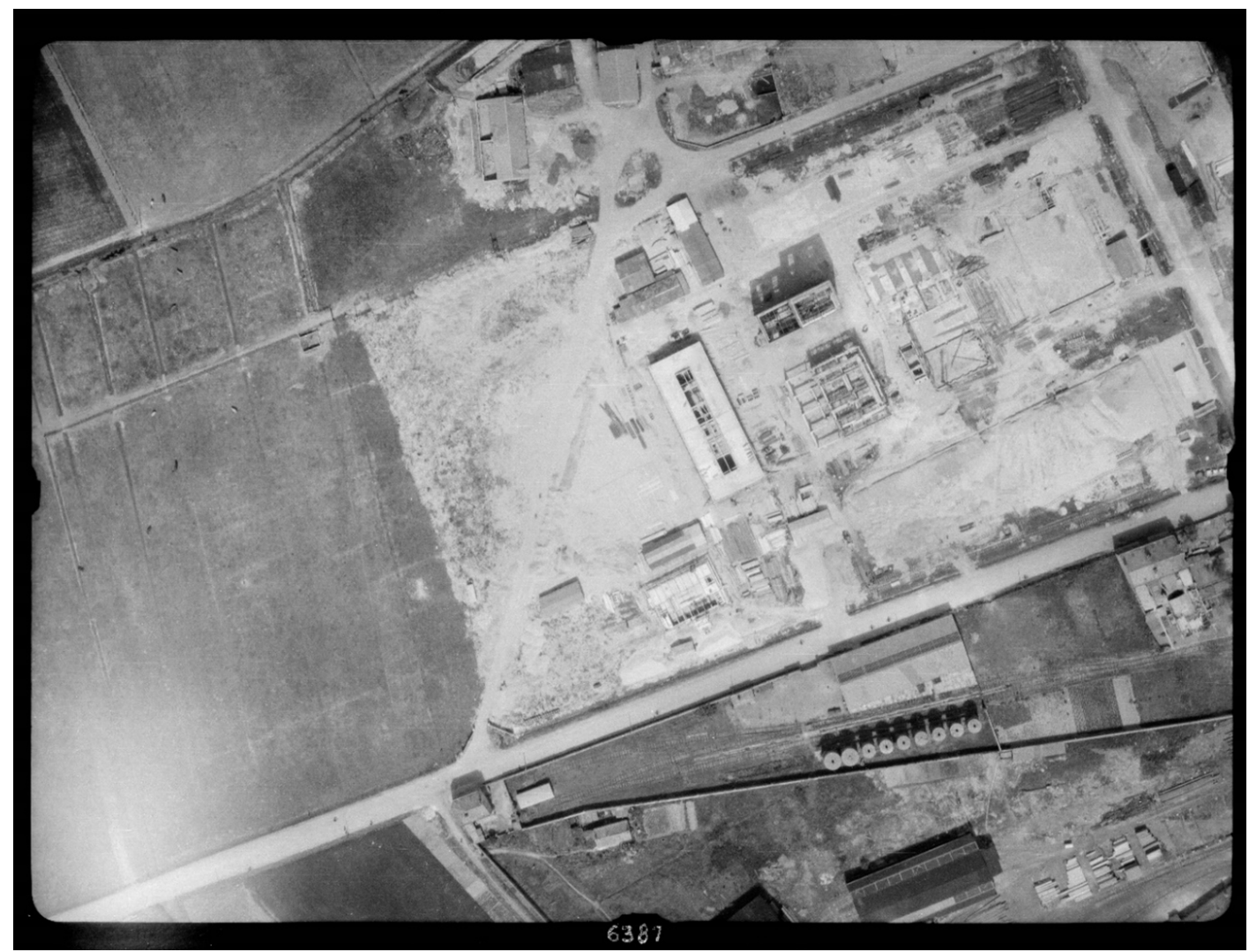

Figure 3. Aerial picture of Dunkirk in 1947, with the alleged second site of Marchand. The railway is visible within the site and leaves on its east part, towards the canal Bourbourg, as explained in the article of Thelliez. Picture of the service "remonter le temps" from the French National Institute of Geographic and forest information, or IGN. (C) IGN

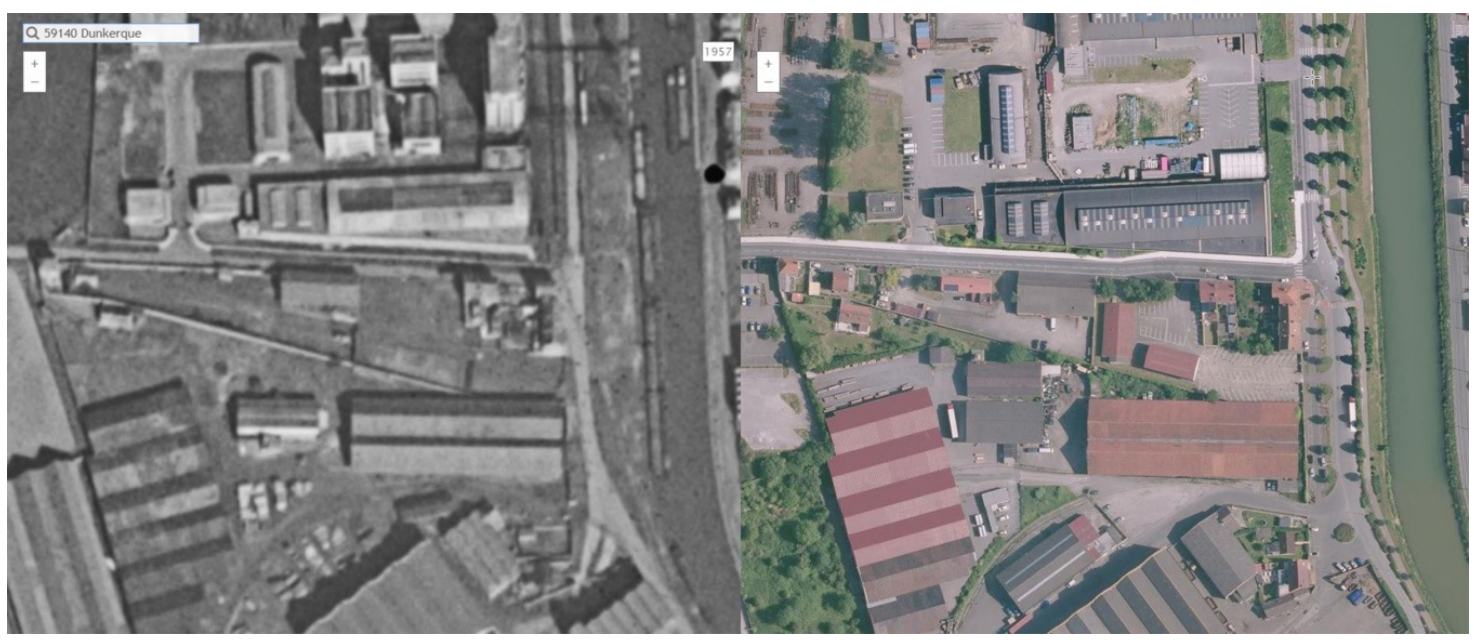

Figure 4. Comparative aerial picture of the second site Marchand in 1957 on the left, and in 2015 on the right. Picture of the service "remonter le temps" from the French National Institute of Geographic and forest information, or IGN. (C) IGN

Beyond the unknown pollution that oil sites created and the lack of information on many others, there are other significant impacts. When the governmental website vaguely locates former oil activities, it can detail if a cleaning process was carried out and whether the function has changed. Sometimes, when geographic information is available, the pollution remained and public and private authorities built houses, shops, parks or schools on these former petroleum sites, as is the case with the old refinery 
of Clère Boilet, among others. The infrastructure disappeared and the condition of the soil remained. Yet, the area now hosts houses, shops and a school. The last known information about the facility is in 1891, regarding an extension of the conditions to run the refinery.

\subsection{Transformation of the Port and the Land: The Mysterious Veiron}

There is one particular case with the site called Veiron, which started in 1900, but the file does not display information on its type or location. On each file, however, there is a short synthesis of the administrative authorization related to the facility. The file of this case shows that the owner asked a transfer for oil storage from one dock to another and provided their names. If the original dock is now a residential area, the second one is more problematic. The file refers to the Freycinet dock, but 12 docks share this name, each with a number. Freycinet was the name of the entire basin of this port area, yet the file does not specify which dock it is talking about.

This case is another example of how historical analysis can reveal forgotten and polluted sites. The minister of public works Freycinet launched the Freycinet plan in 1878, which extended and modernized French ports with canals, railways and infrastructure. The file on Veiron shows the publication of a new authorization for a second site few years after the extension of the port, in 1900. The local Chamber of Commerce asked for a painting of Dunkirk and its port in 1900 for the World Exhibition of Paris available in the Port Museum of the city, which shows a floating dam on one of the basins. A 1910 map from the archives of the Learning Center illustrates this dam and a facility with silos on the last dock of the extension. Together with these evidences, a discussion with the project manager of the museum confirmed later on the oil dedication of this dock, the floating dam preventing burning oil to leak in case of incidents. Hence, the study indicated the possible location of the second Veiron site.

The former Veiron facility is now in a port area partly under water, while the other part became a repairing shipyard. If the latter transformation implies an industrial activity with potential pollution, the underwater zone surely led to the excavation of the polluted soil. Authorities responsible for the extension of the port may have reused it for new docks or any other project. Doing so, they may have moved and spread the pollution from its original position. Most of the area is now an industrial site. If the actual land use limits the impact of past activities on health or the environment, authorities of the city can always reclaim port areas for its expansion.

\subsection{Lost and Ignored Pollution}

Additional elements from various sources also indicated the presence of several pipelines that have existed since 1895 [21]. Built in the fourth basin of the port-formerly dedicated to the transshipment of oil-they went to storage sites in the port or towards the south of the city. The study could not find precise information to locate these pipes, nor any sign of their removal and remediation. One could assume that the development of the port city revealed this infrastructure and that authorities removed it during the urban expansion. However, the question of cleaning remains unsolved, considering the lack of environmental interest of industrial owners and public authorities. On the remaining and still polluted sites referenced, the study found three schools, five residential areas and one wastewater treatment plant.

This transformation of the land use with no previous cleaning is dangerous and worrying. It indicates a real lack of consideration on the condition of the soil by public and private authorities before the Second World War. In France, since 1992, there is a legal commitment to inform any buyer of a land of all previous knowledge on the use of the area (Article L514-20 of the French environmental code) [22]. Yet, schools and houses are still being used on these polluted lands, threatening citizens' health in Dunkirk, and probably in former oil cities around the world. 


\section{The Hand of Oil}

The lack of date base entries on the oil industry in its early stages also had to do with the reluctance of industrial owners towards any kind of legal constraint on their activity. The establishment of an industry was a great economic opportunity for local authorities. Besides, some industrial businessmen provided powerful support to the industry in political and scientific fields against the rise of complaints from neighbors of industrial sites. Dunkirk was a great illustration of this power and its consequences on the local level. However, with the rise of industries as powerful economic actors, their sphere of influence reached, in France, the creation of regulations or policies on industrial activities through their participation in governments. They also became "experts" of national institutes to give their opinion on complaints of citizens on industries. Some documents, in the county archives in Lille, and articles revealed that "experts" deliberately corrupted the data on the impacts of industries on health in reports of national institutes [23].

Sometimes, industrial actors denied the accusation of pollution or the complaints. Industrial owners were rejecting the responsibility on neighboring citizens for living near their factory in letters to local authorities found in the archives of Lille. Putting in place administrative controls on industrial activities was rather uncommon in the 19th century and industrial owners did not easily accept them. Even though early regulations on security and comfort emerged before the industrial development of the oil sector, like the law on polluting industries in 1810, industrial actors slowed down the implementation in their factories [24]. However, with current standards, they would seem ridiculously inefficient, as they were not taking into account the pollution of water or soil, nor the health of workers [25]. For instance, it conditioned authorizations to establish oil facilities to the construction of two meters high walls around the facility and of basins under storages, in case of incident or leak.

The building constraints have remained and evolved with the emergence and the development of environmental and health regulations. Oil companies, now among the most powerful and influential companies in the world, are spending tremendous amounts of money on lobbying in European countries [26-29]. Their objective is to avoid the creation of stricter and limiting measures, mostly environmental rules, which are potentially harmful for their activities [30-32]. Oil lobbyists are especially targeting the European Union, as this supra-national organization has a leading role in creating innovative and powerful health and environmental tools on the continent [33].

The lobbying of petroleum companies to influence the creation or application of international, European or national rules is more visible with the rise of transparency. However, this pressure remains hidden in legal texts. Oil industries are economically strategic and flagships of countries with, for instance, Total for France, British Petroleum for the United Kingdom or Shell for the Netherlands. In such a context, it is difficult for local authorities to negotiate or to be strict in the application of environmental rules, considering the economic benefits that oil companies can generate on their territory. If a policy were to impact the development or the business of such powerful actors, it would definitely affect the economy and the employment rate of port cities.

Yet, the awareness of citizens on protecting nature, health and the quality of life is growing, together with the visible consequences of climate change on their lifestyle and local environment. With the support or threat of the citizen's activism and protests around the world [4], local, national, European and international authorities include more restrictions and obligations to industrial activities. However, the lack of precision in the definition of legal notions and principles creates an absence of anticipation over the detrimental effects of industrial activities, and oil industries in particular.

\section{Conclusions}

Past influences of private and polluting companies influence the present and are a hindrance to the renewal of industrial cities. Their control over the creation of regulations and policies is today an obstacle to the much needed energy transition. Public authorities of Dunkirk are now trying to get away from these carbon-fuels. The pollution "mines", heritage of its past oil activity, hinder the transformation of the port city, and are a threat to inhabitants' health. Past activities of industrial 
cities are often a burden for local authorities, and the oil industry is no different. The end of their activities implies a variety of challenges, from the transformation of the built heritage of the industry to its pollution and the economic impact of its closure on the city. The transition process is often long and painful in such cities. The lack of information on the settlement of old and polluting industries, such as the petroleum one is a challenge for local authorities. Because of this absence of insights on the location of former polluting infrastructure, public and private authorities may have to deal with unexpected contaminated sites during their development strategies. This issue is also a threat to the health of citizens, to which local authorities have a duty to take care. The spread of the pollution prevents, for instance, the land to be used for cultivation or to use the underground water. They are additional obstacles to an already challenging task of renewal for local authorities of industrial cities.

Closing facilities that polluted the soil are already tremendous challenges for their transformation. Yet, past and lost industrial sites are far more troubling for local authorities when trying to locate them. Existing methodologies rely on archives, literature or governmental sources. However, to find elements on these lost industries in specific cities and confirm their location, researchers and public authorities need access to all possible data. Information of the past, gathered from a variety of offline and online sources, is playing a great role in unraveling "pollution mines". The online availability of information and resources is an asset that researchers and public authorities must use in order to create efficient planning policies and transformations of the land. The pollution mines in the city of Dunkirk are only one example of the effects of one industrial activity on the renewal of cities and port cities in particular. The absence of cleaning shows either that public authorities are not aware of the contamination, or worse, that they ignore it. This situation also highlights a lack of interest in past practices and local urban history.

The methodology developed in this paper is an attempt showing the relevance of such combination of traditional research with GIS software and online tools. Local authorities of industrial cities and port cities must develop these cross-analyses if they want to achieve a sustainable transition. The worldwide protests that took place in 2019 in favor of better environmental conditions prove the growing concern of the population for the quality of its environment. The condition of the soil is part of it.

Dunkirk is an example of an industrial port city which needs to transform its former oil sites. The French port city is not the only one in this situation. To meet the challenge of the energy transition, the number of similar cases will inevitably rise with the progressive end of oil activities. Port cities like Antwerp and Rotterdam are still investing in their petroleum infrastructure, as they are major hubs for Northwest European countries. However, the objectives of carbon neutrality in 2050 fixed by the European Commission in its communication (COM (2019) 640) in December 2019 will need the diminution, if not the complete end, of petroleum activities [34].

The methodology developed in this paper can be improved. However, the analysis demonstrates that the development of online data and the use of documents from archives can fill existing gaps in official records. The online availability of historical aerial pictures, old maps and literature makes former difficult, if not impossible, tasks achievable. Many sites related to oil are still missing in the case of Dunkirk, and the article focuses only on petroleum sites. Other industries pre-dated oil, also polluting other areas. Yet, this process can be transferred to these other types of industry and globally improve planning strategies of industrial cities and port cities.

Funding: The research behind this paper was funded by Antea Group and the Learning Center Ville Durable of Dunkirk.

Acknowledgments: I thank Carola Hein, Amy Thomas and my colleagues Penglin Zhu and Gül Aktürk for all their precious comments and support on this paper.

Conflicts of Interest: The author declares no conflict of interest. 


\section{References}

1. Tarigan, A.; Samsura, D.A.; Sagala, S.; Wimbardana, R. Balikpapan: Urban planning and development in anticipation of the post-oil industry era. Cities 2017, 60, 246-259. [CrossRef]

2. Hein, C. Oil Spaces: The Global Petroleumscape in the Rotterdam/The Hague Area. J. Urban Hist. 2018, 44, 887-929. [CrossRef] [PubMed]

3. Mitchell, T. Carbon Democracy: Political Power in the Age of Oil; Verso Books: London, UK, 2011.

4. Laville, S. Top Oil Firms Spending Millions Lobbying to Block Climate Change Policies, Says Report. The Guardian, 22 March 2019.

5. Hein, C. Global Landscapes of Oil. New Geogr. 2010, 2, 33-42.

6. Mega, V.P. Conscious Coastal Cities: Sustainability, Blue Green Growth, and the Politics of Imagination; Springer: Berlin/Heidelberg, Germany, 2016; pp. 39-62, 223-252, 253-268.

7. Fenton, P. Port-City Redevelopment and Sustainable Development. In European Port Cities in Transition: Moving Towards More Sustainable Sea Transport Hubs; Springer Nature Switzerland AG: Basel, Switzerland, 2020; pp. 19-36.

8. Hein, C. "Old Refineries Rarely Die": Port City Refineries as Key Nodes in The Global Petroleumscape. Can. J. Hist. 2018, 53, 450-479. [CrossRef]

9. Hein, C.; van de Laar, P.T. The Separation of Ports from Cities: The Case of Rotterdam. In European Port Cities in Transition: Moving towards More Sustainable Sea Transport Hubs; Springer Nature Switzerland AG: Basel, Switzerland, 2020; pp. 265-286.

10. Delahaye, D.; Folligné, P.; Guermond, Y.; Vapaille, J.-P.; Zambeaux, R. Une recherche sur la pollution des sols de la rive gauche. Études Normandes 1999, 48, 179-186. [CrossRef]

11. Gilliland, J.A.; Novak, M.; Jason, A. Gilliland and Mathew Novak on Positioning the Past with the Present: The Use of Fire Insurance Plans and GIS for Urban Environmental History. Environ. Hist. 2006, 11, 136-139. [CrossRef]

12. Leonard, A.E.; Spellane, P. Using Old Maps and New Methods to Discover the Early Chemicals and Petroleum Industries of Newtown Creek in New York City. J. Map Geogr. Libr. 2013, 9, 25-43. [CrossRef]

13. Moufflet, J.-F. Les archives à la carte: Potentialités de la cartographie numérique pour les archives. Gaz. Arch. 2017, 245, 241-255. [CrossRef]

14. Brétt, D.; Svobodová, E.; Handrychová, B.; Pacina, J. Information System of Vanished Industrial and Technical Culture Heritage in Central Europe. Presented at the 19th International Multidisciplinary Scientific Geoconference, Albena, Bulgaria, 28 June-7 July 2019.

15. Kirkwood, N. Manufactured Sites: Integrating Technology and Design in Reclaimed Landscapes. In Manufactured Sites; Taylor \& Francis: Abingdon, UK, 2003; pp. 16-24.

16. Tempel, N. Post-Industrial Landscapes. In Industrial Heritage Re-Tooled: The TICCIH Guide to Industrial Heritage Conservation; Carnegie Publishing Ltd: Lancaster, UK, 2012; pp. 142-148.

17. Ministère de la Transition Ecologique et Solidaire. Available online: https://www.georisques.gouv.fr (accessed on 6 January 2020).

18. Thelliez, E. Les industries de l'agglomération dunkerquoise. Rev. Nord. 1957, 39, 13-49. [CrossRef]

19. Institut National de l'Information Géographique et Forestière. "Remonter le Temps". Available online: https://remonterletemps.ign.fr (accessed on 6 January 2020).

20. Denise, J. La belle Époque à Dunkerque; Westhoek Edition: Dunkirk, France, 1988; Volume 3.

21. Hein, C.; Stroobandt, C.; de Martino, P. Dunkirk: From oil port to cultural heritage. In Proceedings of the The Resilience of European Port Cities, Dunkerque, France, 17-18 May 2018.

22. Légifrance. Available online: http://www.legifrance.gouv.fr (accessed on 6 January 2020).

23. Le Roux, T. Chemistry and Industrial and Environmental Governance in France, 1770-1830. Hist. Sci. 2016, 54, 195-222. [CrossRef]

24. Le Roux, T. La mise à distance de l'insalubrité et du risque industriel en ville: Le décret de 1810 mis en perspectives (1760-1840). Hist. Mes. 2009, 24, 31-70. [CrossRef]

25. Le Roux, T. L'effacement du corps de l'ouvrier. La santé au travail lors de la première industrialisation de Paris (1770-1840). Mouv. Soc. 2011, 1, 103-119. [CrossRef]

26. InfluenceMap. Big Oil's Real Agenda on Climate Change; InfluenceMap: London, UK, 2019. 
27. Corporate Europe Observatory. The Corporate Europe Observatory Guide to the Murky World of Eu Lobbying. In Lobby Planet Brussels; CEO: Brussels, Belgium, 2017.

28. Vidačak, I. Interest Groups and Lobbying in the European Union. Croat. Int. Relat. Rev. 2003, 9, 177-188.

29. Sidjanski, D. Nouvelles Tendances des Groupes de Pression dans L'union Européenne. In Politiques Publiques en Europe; Editions L'Harmattan: Paris, France, 1995.

30. Hein, C. “Refineries (Oil)”. 2016. Available online: http://philadelphiaencyclopedia.org/archive/refineries-oil/ (accessed on 6 January 2020).

31. Boon, M. Oil Pipelines, Politics and International Business: The Rotterdam Oil Port, Royal Dutch Shell and the German Hinterland, 1945-1975; Erasmus School of History, Culture and Communication (ESHCC): Rotterdam, The Netherlands, 2014.

32. Watts, J. Concerns as Eu Bank Balks at Plan to Halt Fossil Fuel Investments. The Guardian, 15 October 2019.

33. Romi, R. Droit International et Européen de L'environnement, 3rd ed.; LGDJ: Paris, France, 2017.

34. European Union. "EUR-Lex", 1998-2020. Available online: https://eur-lex.europa.eu/ (accessed on 28 January 2020).

(C) 2020 by the author. Licensee MDPI, Basel, Switzerland. This article is an open access article distributed under the terms and conditions of the Creative Commons Attribution (CC BY) license (http://creativecommons.org/licenses/by/4.0/). 